\title{
Organic-Inorganic doped Nickel Oxide Nanocrystals for Hole Transport Layers in Inverted Polymer Solar Cells with Color Tuning
}

\author{
Riva Alkarsifi ${ }^{1}$, Yatzil Alejandra Avalos-Quiroz ${ }^{1}$, Pavlo Perkhun ${ }^{1}$, Xianjie Liu ${ }^{2}$, Mats \\ Fahlman $^{2}$, Anil Kumar Bharwal ${ }^{3}$, Carmen M. Ruiz ${ }^{3}$, David Duché ${ }^{3}$, Jean-Jacques Simon ${ }^{3}$, \\ Christine Videlot-Ackermann ${ }^{1}$, Olivier Margeat ${ }^{1 *}$ and Jörg Ackermann ${ }^{1 *}$ \\ ${ }^{1}$ Aix Marseille Univ, CNRS, CINaM, FUN-PV group, Marseille, France. \\ ${ }^{2}$ Laboratory for Organic Electronics, ITN, Linköping University, Norrköping, Sweden. \\ ${ }^{3}$ Aix Marseille Univ, Université de Toulon, CNRS, IM2NP, FUN-PV group, Marseille, \\ France.
}

[*] Corresponding Authors:

E-mail address: olivier.margeat@univ-amu.fr

ackermann@cinam.univ-mrs.fr

\section{KEYWORDS:}

Nickel oxide; doping; interfacial layer; morphology; hole transport; solar cell.

\begin{abstract}
$\underline{\text { Abstract }}$
Polymer solar cells using non-fullerene acceptors are nowadays amongst the most promising approaches for next generation photovoltaic applications. However, there are still remaining challenges related to large-scale fully solution-processing of high efficiency solar cells as high efficiencies are obtained only at very small areas using hole transport layers based on evaporated molybdenum oxide. Solution-processable hole transport materials compatible with non-fullerene acceptor materials are still scarce and thus considered as one of the major challenges nowadays. In this work, we present copper-doped nickel oxide nanocrystals that form highly stable inks in alcoholic-based solutions. This allows processing efficient hole transport layers in both regular and inverted device structures of polymer solar cells. As the initial work function of these ionic doped materials is too low for efficient hole extraction, doping the nanocrystals with an organic electron acceptor, namely 2,3,5,6-tetrafluoro-7,7,8,8tetracyanoquino dimethane (F4-TCNQ) was additionally applied to make the work function more suitable for hole extraction. The resulting hybrid hole transport layers were first studied in polymer solar cells based on fullerene acceptors using regular device structures yielding in $7.4 \%$ efficiency identical to reference cells based on poly (3,4-ethylenedioxythiophene) polystyrene sulfonate (PEDOT:PSS). For inverted device structures, the hybrid hole transport layers were processed on top of blends based on the non-fullerene acceptor IT-4F and PBDB$\mathrm{T}-2 \mathrm{~F}$ donor. The corresponding solar cells lead promising efficiencies up to $7.9 \%$ while the reference devices using PEDOT:PSS show inferior performances. We further show that the hybrid hole transport layer can be used to tune the color of the polymer solar cells using optical spacer effects.
\end{abstract}




\section{Introduction}

The low cost, flexibility, light weight and solution-processability enable the polymer solar cells (PSC) technology to be used in large-scale industrial applications. The intense researches in the field of polymer photovoltaics during the last 10 years brought the power conversion efficiency (PCE) up to over $18 \% .{ }^{1}$ This high efficiency drives PSCs to be one of the most promising new generation of photovoltaic solar panels. This technological progress was made possible by developing new materials in the active layer, especially the new low band gap donor materials as well as the non-fullerene acceptors (NFAs). The presence of interfacial layers (ILs) between the photoactive layer and the electrodes is also one of the critical aspects for the fabrication of highly efficient and stable optoelectronic devices. Efficient ILs improve the charge carrier extraction toward the electrodes, avoid non ohmic contact losses as well as charge carrier recombination and exciton quenching at the interfaces. ${ }^{2}$ Typically, an effective hole transport layer (HTL) should possess good optical transparency and efficient electron-blocking ability with suitable hole transport properties. ${ }^{3}$ Furthermore, the conductivity should be high enough to process layers up to several hundreds of nanometers to guaranty robust printing of HTLs. Poly(3,4-ethylenedioxythiophene):poly(styrene-sulfonate) (PEDOT:PSS) with a work function (WF) of $5.10 \mathrm{eV}$ has been widely used as a HTL in regular device structures. ${ }^{4}$ It has even been used, in its highly conductive formulations, after treatments with acid ${ }^{5}$ or polar solvents, ${ }^{6}$ as electrode itself for ITO replacement.

Despite the high efficiencies obtained, most of the commercial PEDOT:PSS solutions have a $\mathrm{pH}$ value between 1 and 3 at $20^{\circ} \mathrm{C}$ that causes etching of indium from ITO electrode. The indium diffusion into the photoactive layer induces fast device degradation. Thus, to overcome the acidity problem, and thereby improve device stability, Meng et al. ${ }^{7}$ introduced $\mathrm{pH}$ neutral PEDOT:PSS as HTL in bulk heterojunction (BHJ) devices with a photoactive layer of poly[N9"'-hepta-decanyl-2,7-carbazole-alt5,5-(4',7'-di-2-thienyl-2',1',3'-benzothiadiazole] (PCDTBT) and $[6,6]$-phenyl $\mathrm{C} 71$ butyric acid methyl ester $\left(\mathrm{PC}_{70} \mathrm{BM}\right)$. Interestingly, the double treatment of the $\mathrm{pH}$-neutral PEDOT:PSS surface with UV-ozone and oxygen plasma not only improves the PCE to $6.60 \%$ when compared to the acidic PEDOT:PSS-based devices $(6.28 \%)$ but also enhances air stability.

However, as PEDOT:PSS is highly hydrophilic, processing inverted device structures in which PEDOT:PSS has to be solution-processed on top of the photoactive layer leads to poor film morphology and worse electrical properties. ${ }^{8}$ Such wettability problems on hydrophobic surfaces can be solved by adding proper additives capable of reducing the hydrophilic nature of PEDOT:PSS. However, by using modified PEDOT:PSS HTLs for inverted device structures, still low efficiencies were obtained. ${ }^{8,9,10}$ Thus, these limitations necessitate the replacement of PEDOT:PSS with other solution-processed hole transport materials, ${ }^{11}$ especially for processing inverted device structures. Other materials stand out as promising candidates to replace PEDOT:PSS HTLs such as the well-known stable transition metal oxides (TMOs) including molybdenum oxide $\left(\mathrm{MoO}_{3}\right)$, tungsten oxide $\left(\mathrm{WO}_{3}\right)$, vanadium oxide $\left(\mathrm{V}_{2} \mathrm{O}_{5}\right)$, and nickel oxide $\left(\mathrm{NiO}_{\mathrm{x}}\right)^{11,12}$ and ternary metal oxides. ${ }^{13,14,15}$ Indeed for the later ones, the features of low-cost, low-temperature, simplicity, ligand-free, and solution processability expose the opportunities to be used for large-scale and flexible high performance PSCs.

Among all metal oxides, $\mathrm{NiO}_{\mathrm{x}}$ shows advantages including good electron-blocking ability, $\mathrm{p}$ type conductivity and wide band gap with high ionization potential that promotes an ohmic contact at the $\mathrm{BHJ} /$ anode interface. ${ }^{16}$ Additionally, the valence band of $\mathrm{NiO}_{\mathrm{x}}$ is well aligned with the highest occupied molecular orbital (HOMO) levels of many typical p-type conjugated polymers for hole transport which is distinct from other typical oxide-based materials. ${ }^{17,18}$ 
$\mathrm{NiO}_{\mathrm{x}}$ HTLs have been prepared for PSCs by various processing methods, such as pulsed laser deposition, ${ }^{19}$ sputtering, ${ }^{20}$ thermal evaporation, ${ }^{21}$ atomic layer deposition ${ }^{22}$ and solution processes. ${ }^{23}$ Among these, solution-processed methods are highly desirable as they meet the requirements for low-cost, large-scale and roll-to-roll production.

Primary, the studies on solution-processed $\mathrm{NiO}_{x}$ HTLs were focused on utilizing the sol-gel method. ${ }^{24}$ Normally, this method requires post-treatments such as high temperature annealing or oxygen-plasma exposure to convert the deposited precursor solution into $\mathrm{NiO}_{\mathrm{x}}$ thin films. Such treatments limit the incorporation of the prepared $\mathrm{NiO}_{\mathrm{x}}$ in flexible and inverted device structures. Thus, an alternative colloidal nanocrystal approach is favored. The main advantage of this approach is decoupling the particle synthesis from the film-formation process with the utilization of lower temperature annealing $\operatorname{step}^{18,25}$, allowing for their use in flexible and inverted PSCs. ${ }^{26}$

In this work, we focused on the solution-processed $\mathrm{NiO}_{\mathrm{x}}$ HTLs prepared by the chemical precipitation method. So far, pristine $\mathrm{NiO}_{\mathrm{x}}$ nanoparticles (NPs) synthesized using the chemical precipitation method were employed mostly for inverted-based perovskite solar cells. ${ }^{27,28,29}$ The only example utilizing the chemically precipitated aqueous $\mathrm{NiO}_{x}$ solutions in PSCs was given by Jiang et al. ${ }^{18}$ The HTLs were prepared by spin-coating without any post-treatments during device fabrication and resulted in PCE of $9.16 \%$ and $7.96 \%$ with PTB7-Th: $\mathrm{PC}_{70} \mathrm{BM}$ and PTB7:PC $70 \mathrm{BM}$-based regular PSCs, respectively. Importantly, the reported $\mathrm{NiO}_{\mathrm{x}} \mathrm{NPs}$ were dispersed in water, thus they are not compatible for processing on top of hydrophobic photoactive layers. Recently, self-assembled quasi-3D nanocomposite of $\mathrm{NiO}_{\mathrm{x}}$ nanocrystals and graphene oxide (GO) nano-sheets in ethanol have been developed for highly efficient and stable inverted organic solar cells based on fullerene and non-fullerene acceptors. Due to enhanced conductivity and electron blocking ability of the nanocomposite, $\mathrm{J}_{\mathrm{SC}}$ and FF were both enhanced and the highest PCE obtained was $12.31 \%$ using a combination of the polymer donor named poly[(2,6-(4,8-bis(5-(2-ethylhexyl)thiophen-2-yl)benzo[1,2-b:4,5-b']dithiophene)-co-(1,3-di(5 -thiophene-2-yl)5,7-bis(2-ethylhexyl)-benzo[1,2-c:4,5-c']dithiophene-4,8-dione)] (PBDB-T) and the non-fullerene acceptor named 3,9-bis(2-methylene-((3-(1,1-dicy anomethylene)-6/7methyl)-indanone))-5,5,11,11-tetrakis(4-hexylphenyl)-dithieno[2,3d:2',3'-d']-s-indaceno [1,2b:5,6-b']dithiophene (IT-M). ${ }^{30}$ The self-assembled quasi-3D nanocomposite could also break the conductivity limitation of the 2D-GO material, as up to $32 \mathrm{~nm}$ thick HTLs could be included in the device without generation of any important performance loss. To further increase layer thickness and thus processing robustness of HTLs for industrial printing processes, the increase of electrical conductivity of $\mathrm{NiO}_{\mathrm{x}}$, via metal ion doping is an effective approach. Jung et al. ${ }^{31}$ demonstrated a Cu-doped $\mathrm{NiO}_{\mathrm{x}}$ HTL prepared via combustion method with greatly enhanced electrical conductivity that improved the performance of the inverted planar perovskite solar cells to $17.74 \%$. For solution-processed $\mathrm{Cu}$-doped $\mathrm{NiO}_{\mathrm{x}}$ prepared by chemical precipitation method, the only example was given for the inverted-based structure of perovskite solar cells. ${ }^{32}$ Thus, up to our knowledge, there exists no reported chemically precipitated $\mathrm{Cu}-\mathrm{NiO}_{\mathrm{x}} \mathrm{HTLs}$ used for both regular and inverted device structures of PSCs.

Herein, we developed a strategy to produce chemically precipitated $\mathrm{Cu}-\mathrm{NiO}_{\mathrm{x}} \mathrm{NPs}$ that form aggregate-free solution in isopropanol (IPA) suitable for processing the HTL on top of photoactive layers. We found out that $\mathrm{Cu}$ doping level impacts directly the solubility of $\mathrm{Cu}-$ $\mathrm{NiO}_{x}$ NPs in IPA. This allows in optimal conditions to obtain highly soluble NPs solutions stable over several months. The $\mathrm{Cu}-\mathrm{NiO}_{\mathrm{x}}$ IPA solutions were used to process both regular and inverted-based device structures of PSCs. The initial work function of $\mathrm{Cu}-\mathrm{NiO}_{\mathrm{x}} \mathrm{HTLs}$ was found around $4.5 \mathrm{eV}$ and had to be increased in order to prevent energy loss at the interfaces. ${ }^{33}$ 
By introducing a strong electron acceptor such as 2,3,5,6-tetrafluoro-7,7,8,8-tetracyanoquinodimethane (F4-TCNQ) into $\mathrm{Cu}-\mathrm{NiO}_{\mathrm{x}}$ layers, the WF was tuned from $4.47 \mathrm{eV}$ to $5.45 \mathrm{eV}$, favoring an energy level alignment of $\mathrm{Cu}-\mathrm{NiO}_{\mathrm{x}}$ with several donor materials having different HOMO energy levels. F4-TCNQ is a well-known p-type dopant used to dope not only interfacial layers but also photoactive layers. ${ }^{34}$ The organic-inorganic doped $\mathrm{NiO}_{\mathrm{x}}$ nanoparticle composites form highly effective HTLs for regular device structure, leading to PCEs of 7.4\% in fullerene solar cells using PTB7:PC 70 BM blends. Applied to NFA-based solar cells using the polymer donor named poly[(2,6-(4,8-bis(5-(2-ethylhexyl-3-fluoro)thiophen-2-yl)-benzo[1,2b:4,5-b']dithiophene))-alt-(5,5-(1',3'-di-2-thienyl-5',7'-bis(2-ethylhexyl)benzo[1',2'-c:4',5'c' ]dithiophene-4,8-dione)] (PBDB-T-2F) and the non-fullerene acceptor named 3,9-bis(2methylene-((3-(1,1-dicyanomethylene)-6,7-difluoro)-indanone))-5,5,11,11-tetrakis(4hexylphe nyl)-dithieno[2,3-d:2',3'-d']-s-indaceno[1,2-b:5,6-b']dithiophene (IT-4F) with inverted device structure, these hybrid HTLs lead to PCE of $7.9 \%$ compared to $11 \%$ obtained with evaporated $\mathrm{MoO}_{\mathrm{x}}$ as well as $6.3 \%$ reached with PEDOT:PSS. In both normal and inverted device structures, the losses are induced by optical losses and not by the thickness of the HTL. This demonstrates that the developed solution-processed organic-inorganic $\mathrm{Cu}-\mathrm{NiO}_{\mathrm{x}} \mathrm{NPs}$ are a first step towards efficient HTLs for NFA-based solar cells with inverted device structures without thickness limitation. Additionally, we show for the first time that $\mathrm{Cu}-\mathrm{NiO}_{\mathrm{x}} \mathrm{HTLs}$ can introduce the socalled optical spacer (OSP) effects in inverted device structures that were so far only reported in regular structures using electron transport materials (such as $\mathrm{ZnO}$ ). ${ }^{35}$ These OSPs modify the light distribution inside the devices, ${ }^{36}$ allow color tuning and optimize the generated photocurrent of the PBDB-T-2F:IT-4F based polymer solar cells by simply varying the thicknesses of both the photoactive layer and the $\mathrm{Cu}-\mathrm{NiO}_{\mathrm{x}} \mathrm{HTL}$.

\section{Results and discussion}

\subsection{Synthesis and characterization of nickel oxide nanoparticles}

Non-stoichiometric $\mathrm{NiO}_{\mathrm{x}} \mathrm{NPs}$ were obtained using the chemical precipitation method reported by Jiang et al. ${ }^{18}$ with some modifications starting with the commercially available nickel nitrate hexahydrate $\left(\mathrm{Ni}\left(\mathrm{NO}_{3}\right)_{2} \cdot 6 \mathrm{H}_{2} \mathrm{O}\right)$ and sodium hydroxide $(\mathrm{NaOH})$. These materials were easily dissolved in deionized water. After the dropwise addition of $\mathrm{NaOH}$ into the nickel nitrate, the clear green aqueous solution turned turbid. Through accurately controlling the solution $\mathrm{pH}$ value to 10 , nickel hydroxide $\mathrm{Ni}(\mathrm{OH})_{2}$ was obtained in a considerable yield. The obtained apple green product was washed twice then dried and calcined at $270{ }^{\circ} \mathrm{C}$ for 2 hours in air to produce dark-black powder. This calcination procedure was based on the thermal decomposition of $\mathrm{Ni}(\mathrm{OH})_{2}$ to produce non-stoichiometric $\mathrm{NiO}_{\mathrm{x}} \mathrm{NPs}$. In fact, the $270{ }^{\circ} \mathrm{C}$ is the optimal calcination temperature for $\mathrm{NiO}_{\mathrm{x}}$ that allows the presence of small amounts of unreacted nickel hydroxide and nitrate ions critical for stabilizing the dispersion. ${ }^{28}$

The same procedure was followed for synthesizing $\mathrm{Cu}$-doped $\mathrm{NiO}_{\mathrm{x}}$ but with the addition of copper nitrate hydrate $\left(\mathrm{Cu}\left(\mathrm{NO}_{3}\right)_{2} \cdot \mathrm{xH}_{2} \mathrm{O}\right)$ metal precursor in the starting solution. $\mathrm{Cu}-\mathrm{NiO}_{\mathrm{x}} \mathrm{NPs}$ with copper doping levels ranging from $2 \%$ up to $20 \%$ were produced by varying the initial molar ratio of the metal precursor with respect to the nickel nitrate while keeping all the other parameters and synthetic steps unchanged. Importantly, and as expected, it was proven that the nominal doping levels corresponding to the initial precursor ratios of the metal dopants to nickel atoms, have resulted in lower doping levels inside the NPs as determined by elemental analysis using an Atomic Absorption Spectroscopy (AAS). The results are summarized in Table S-1. 
Transmission Electron Microscopy (TEM) analysis was performed to determine the particle size and the crystallinity of the $\mathrm{NiO}_{\mathrm{x}} \mathrm{NPs}$. Figure $\mathbf{1 a}$ and $\mathbf{1 b}$ present the low magnification TEM images of the pristine $\mathrm{NiO}_{\mathrm{x}}$ and the $\mathrm{Cu}-\mathrm{NiO}_{\mathrm{x}(12.2 \%)} \mathrm{NPs}$, respectively. It was obvious that the crystal size of the doped $\mathrm{NiO}_{x} \mathrm{NPs}(5 \mathrm{~nm})$ was smaller than that of the pristine $\mathrm{NiO}_{\mathrm{x}}$ NPs $(10 \mathrm{~nm})$. Meanwhile, both of them show clear lattice fringes, suggesting good crystalline properties of these NPs.
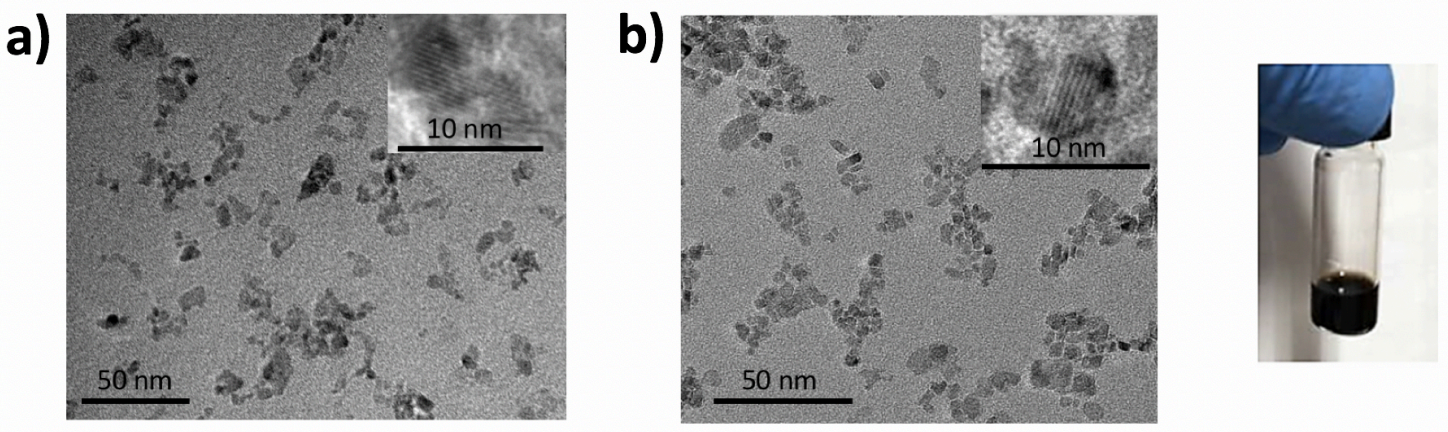

Figure 1. TEM images of non-stochiometric (a) pristine $\mathrm{NiO}_{\mathrm{x}}$ and (b) $\mathrm{Cu}-\mathrm{NiO}_{\mathrm{x}(12.2 \%)} \mathrm{NPs}$ with scale bar of $50 \mathrm{~nm}$.

X-Ray Diffraction (XRD) measurements were performed to explore the crystal structure of both pristine and $\mathrm{Cu}$-doped $\mathrm{NiO}_{x} \mathrm{NPs}$. XRD diffractograms are shown in Figure 2a. The diffraction peaks of the pristine $\mathrm{NiO}_{\mathrm{x}} \mathrm{NPs}$ revealed cubic crystal structure with three prominent characteristic diffraction peaks at $37.29^{\circ}, 43.34^{\circ}$ and $62.91^{\circ}$, which could be assigned to (111), (200) and (220) planes of $\mathrm{NiO}_{x}$, respectively. Meanwhile, no extra diffraction peaks related to metallic $\mathrm{Cu}$ or to copper oxide phase were observed in the XRD diffractogram of $\mathrm{Cu}$-doped $\mathrm{NiO}_{\mathrm{x}} \mathrm{NPs}$, indicating that doping with $\mathrm{Cu}$ did not hardly change the phase structure of $\mathrm{NiO}_{\mathrm{x}}$. Furthermore, it could be observed that the diffraction peaks were slightly shifted toward lower angles upon increasing the $\mathrm{Cu}$-doping content. This suggests that the lattice parameter of $\mathrm{NiO}_{\mathrm{x}}$ was increased upon doping. This was originated from the substitution of $\mathrm{Ni}$ ions (ionic radius: $69 \mathrm{pm}$ ) with the slightly larger $\mathrm{Cu}$ ions (ionic radius: $73 \mathrm{pm}$ ). ${ }^{37}$ The broadening of the diffraction peaks by increasing the content of $\mathrm{Cu}$ ions from 2 to $15 \%$ could be related to the presence of smaller crystallites since the incorporation of impurities in oxide semiconductors is known to suppress the grain growth and thus results in smaller particles. ${ }^{32}$ These results are in consistence with the TEM results.

Although no crystal phase other than $\mathrm{NiO}_{x}$ was detected using XRD, X-Ray Photoelectron Spectroscopy (XPS) measurements were done to demonstrate the effective doping of the $\mathrm{NiO}_{x}$ NPs with $\mathrm{Cu}$ and to investigate the chemical components of the pristine and the doped $\mathrm{NiO}_{\mathrm{x}}$ films. The XPS spectra for the pristine $\mathrm{NiO}_{\mathrm{x}}$ films are shown in Figure $\mathbf{2 b}$. The $\mathrm{Ni} 2 \mathrm{p}_{3 / 2}$ level at $860 \mathrm{eV}$ and the $\mathrm{O} 1 \mathrm{~s}$ level at $532.2 \mathrm{eV}$ correspond to the $\mathrm{Ni}^{3+}$ state of the $\mathrm{NiOOH}$ species. The $\mathrm{Ni} 2 \mathrm{p}_{3 / 2}$ level at $855 \mathrm{eV}$ and the $\mathrm{O} 1 \mathrm{~s}$ level at $531 \mathrm{eV}$ peaks can be assigned to the $\mathrm{Ni}^{3+}$ state of the $\mathrm{Ni}_{2} \mathrm{O}_{3}$. In addition, the presence of the $\mathrm{Ni}^{2+}$ state of $\mathrm{NiO}_{\mathrm{x}}$ is revealed by the Ni $2 p_{3 / 2}$ level at 853.6 and $\mathrm{O} 1 \mathrm{~s}$ level at $529 \mathrm{eV}$ peaks as well as the $\mathrm{Ni} 2 \mathrm{p}_{1 / 2}$ peak and its satellites at 873.6 and $878.5 \mathrm{eV}$. These results are in consistence with the XPS measurements of the previously synthesized $\mathrm{NiO}_{\mathrm{x}} \mathrm{NPs}$ by Jiang et al. ${ }^{18}$ The coexistence of $\mathrm{Ni}^{2+}$ and $\mathrm{Ni}^{3+}$ states is a confirmation of the non-stoichiometric nature of the $\mathrm{NiO}_{\mathrm{x}}$. The XPS spectra of the $\mathrm{Cu}-\mathrm{NiO}_{\mathrm{x}}(12.2 \%)$ films proved that $\mathrm{Cu}$ atoms have been successfully incorporated into the $\mathrm{NiO}_{\mathrm{x}}$ 
NPs due to the presence of two peaks located at 933.3 and $953.5 \mathrm{eV}$ corresponding to $\mathrm{Cu} 2 \mathrm{p}_{3 / 2}$ and $\mathrm{Cu} 2 \mathrm{p}_{1 / 2}$ levels, respectively. These peaks revealed that $\mathrm{Cu}^{2+}$ ions substituted the $\mathrm{Ni}$ atom in the $\mathrm{NiO}_{\mathrm{x}}$ crystal lattice. ${ }^{32}$
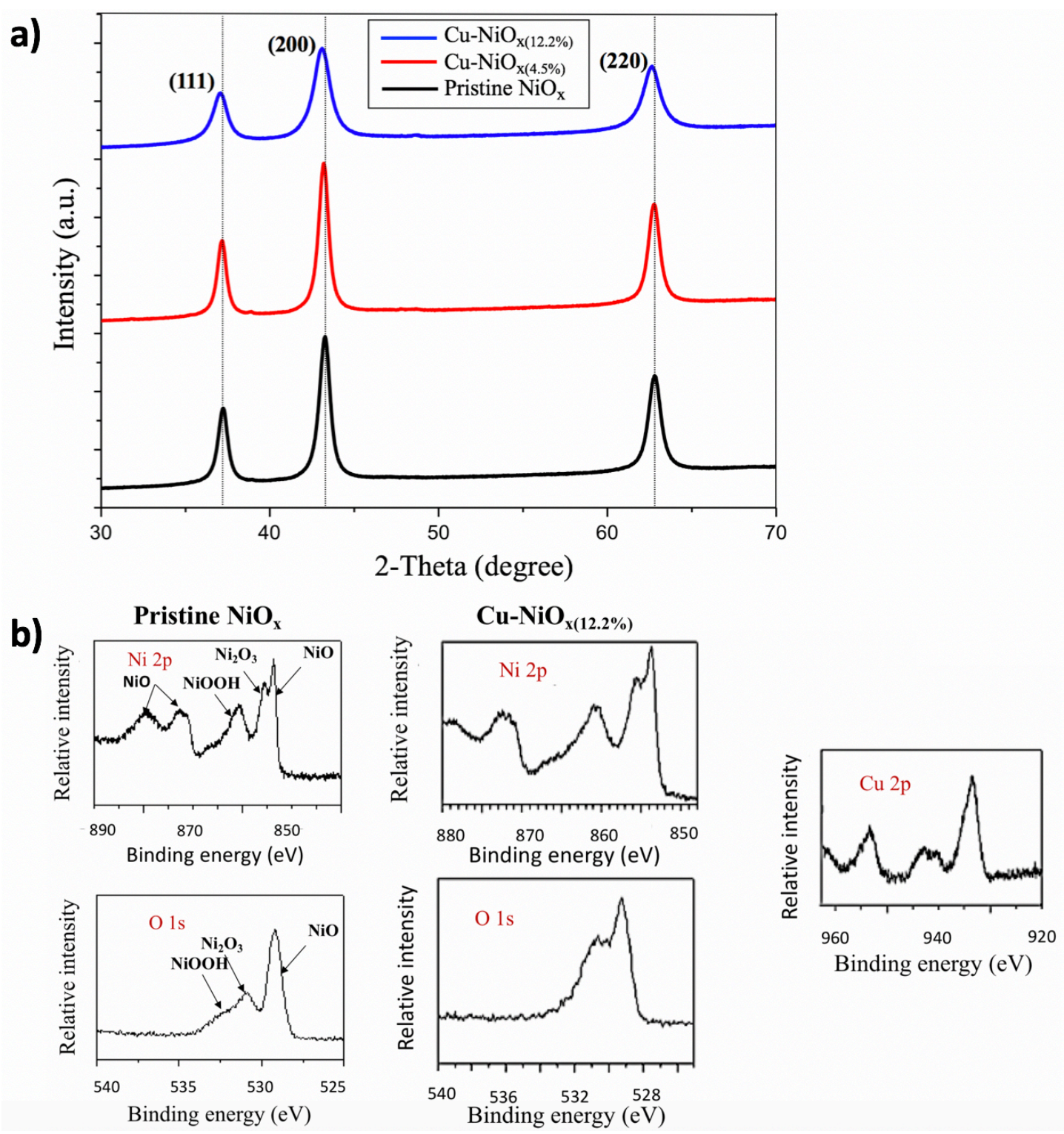

Figure 2. (a) XRD diffractograms and (b) XPS spectra of the pristine and the $\mathrm{Cu}-\mathrm{NiO}_{\mathrm{x}(12.2 \%)}$ films showing the $\mathrm{Ni} 2 \mathrm{p}, \mathrm{O} 1 \mathrm{~s}$ and $\mathrm{Cu} 2 \mathrm{p}$ core level peaks.

The ultraviolet-visible (UV-vis) absorption spectra of the $\mathrm{NiO}_{\mathrm{x}}$ solutions were primarily used to find any possible modification in the energy band structure upon doping. As can be observed in Figure S-1, the absorption edge was red-shifted to the visible region upon $\mathrm{Cu}$ doping. This indicates the narrowing of the optical band gap. The band gap of the pristine $\mathrm{NiO}_{\mathrm{x}}$ as determined from Tauc plot $(3.74 \mathrm{eV})$ is in good agreement with the reported band gaps. ${ }^{32} \mathrm{By}$ increasing the $\mathrm{Cu}$-doping level, the band gap was decreased to 3.65, 3.6 and $3.56 \mathrm{eV}$ for $\mathrm{Cu}$ $\mathrm{NiO}_{\mathrm{x}(2.4 \%)}, \mathrm{Cu}-\mathrm{NiO}_{\mathrm{x}(12.2 \%)}$ and $\mathrm{Cu}-\mathrm{NiO}_{\mathrm{x}(28.2 \%)}$, respectively. It was reported that the particle size in the metal oxide systems may affect the electronic properties (such as the band gap) of the NPs due to quantum confinement effect. However, it was also proven that not only quantum confinement can 
affect the electronic structure, but also doping can have an impact by introducing defect centers into the lattice. These defects can interact with the host lattice to alter the band structure and cause large changes in their properties. ${ }^{38}$ This phenomenon proved again that $\mathrm{Cu}$ was successfully included into the $\mathrm{NiO}_{\mathrm{x}} \mathrm{NPs}$.

\subsection{Solution-processing of $\mathrm{NiO}_{\mathrm{x}}$ nanocrystals $(\mathrm{NCs})$}

\subsubsection{Alcoholic-based $\mathrm{NiO}_{x}$ solutions}

Pristine and the $\mathrm{Cu}$-doped $\mathrm{NiO}_{\mathrm{x}}$ nanoparticles with different doping percentage levels can be easily dispersed in water as mentioned elsewhere in literature. ${ }^{25}$ It is worth mentioning that the dispersion was dependent on the $\mathrm{pH}$ during synthesis. $\mathrm{A} \mathrm{pH}$ of 10 results in a better dispersion, while any further increase in the basicity of the medium decreases the dispersion of the NPs. This can be related to a previous study showing the effect of $\mathrm{pH}$ on the outcome of the precipitation reaction. Nickel salt solutions tend to be acidic $(\mathrm{pH} \approx 3)$ and upon the addition of a strong alkali, precipitation takes place at $\mathrm{pH}=5.5-6$. Thus, it was proven that $\mathrm{Ni}(\mathrm{OH})_{2}$ produced at $\mathrm{pH}=10-12$ is a material deficient in hydroxyl ions and requires the inclusion of nitrates for charge neutrality. However, the NPs produced at higher $\mathrm{pH}$ are stoichiometric. Therefore, the increase in the basicity of the medium eliminates the presence of nitrates. ${ }^{39} \mathrm{On}$ its turn, Jaramillo and coworkers ${ }^{28}$ proved the importance of the presence of an amorphous phase containing nitrates, sodium and hydroxides to get a better dispersion of the $\mathrm{NiO}_{\mathrm{x}} \mathrm{NPs}$. Thus, not only the calcination temperature but also the $\mathrm{pH}$ have an effect on the dispersion of the $\mathrm{NiO}_{\mathrm{x}} \mathrm{NPs}$ by affecting the final $\mathrm{Ni}(\mathrm{OH})_{2}$ surface product.

It is known that the water-based $\mathrm{NiO}_{\mathrm{x}}$ solutions can be easily deposited on top of ITO substrates. However, it is not possible to directly deposit such aqueous solutions on top of photoactive layers in PSCs. As seen in the AFM image of Figure 3a, the deposition of $\mathrm{Cu}-\mathrm{NiO}_{\mathrm{x}(12.2 \%)}$ solution on top of $\mathrm{PTB} 7: \mathrm{PC}_{70} \mathrm{BM}$ photoactive layer resulted in a bad morphology due to the poor wettability of the water-based solutions on the hydrophobic organic blend. This effect is similar to the case of water-based PEDOT:PSS solutions. Normally, wetting agents such as 2,5,8,11-tetramethyl-6-dodecyn-5,8-diolethoxylate (Dynol 604), Zonyl FS300 fluorosurfactant (Zonyl) ${ }^{40}$ or Triton- $\mathrm{X}^{41}$ can be added to the PEDOT:PSS water-based solution to decrease the surface tension, thus improving the wettability on top of photoactive layers. However, such additives showed no effect with the synthesized $\mathrm{NiO}_{\mathrm{x}} \mathrm{NPs}$. Therefore, we followed another strategy to transfer the $\mathrm{NiO}_{\mathrm{x}}$ dispersion from water into isopropanol by using probe ultrasonication in a mixture of water, isopropanol and methoxy acetic acid surfactant that stabilizes the $\mathrm{Cu}-\mathrm{NiO}_{\mathrm{x}} \mathrm{NPs}$ when transferred into IPA solution. The use of this intermediate step allows producing monodispersed cluster-free IPA-based $\mathrm{NiO}_{\mathrm{x}}$ solutions. Dynamic Light Scattering (DLS) measurements shows that the size of the aggregate inside the isopropanolbased solutions corresponds to the size of single NC as determined by TEM.

Additionally, we found that the doping level of the $\mathrm{Cu}-\mathrm{NiO}_{\mathrm{x}} \mathrm{NPs}$ impacts the dispersion of the nanoparticles in IPA. Indeed, the highest solubility and most stable solution in IPA were found for $12.2 \%$ of $\mathrm{Cu}$-doping, while pristine $\mathrm{NiO}_{\mathrm{x}}$ or NPs with other doping levels showed lower stability. Importantly, the $\mathrm{Cu}-\mathrm{NiO}_{\mathrm{x}(12.2 \%)}$ IPA-based solutions were stable for more than six months without occurrence of any NCs aggregation, as confirmed by regular DLS measurements, unlike the aqueous-based solutions having stability not exceeding few days as can be seen in Figure S-2. 


\subsubsection{Thin film processing}

Taking into account the importance of the film quality for efficient charge extraction, ${ }^{42}$ we studied the morphology of the IPA-based $\mathrm{Cu}-\mathrm{NiO}_{\mathrm{x}}$ films on ITO substrates as well as on photoactive layers based on PTB7:PC 70 BM blends by using AFM. As shown in Figure S-3, closely-packed layers were observed on ITO with a low surface roughness of $6 \mathrm{~nm}$ for the 40 $\mathrm{nm}$-thick $\mathrm{Cu}-\mathrm{NiO}_{\mathrm{x}(12.2 \%)}$ layers. Interestingly, the morphology of the $\mathrm{Cu}-\mathrm{NiO}_{\mathrm{x}}$ layer processed on PTB7:PC $70 \mathrm{BM}$ is also compact with a $7 \mathrm{~nm}$ surface roughness (Figure 3b). This indicates that the IPA-based $\mathrm{Cu}-\mathrm{NiO}_{\mathrm{x}} \mathrm{NPs}$ are well adapted for the solution-processing in inverted device structures.
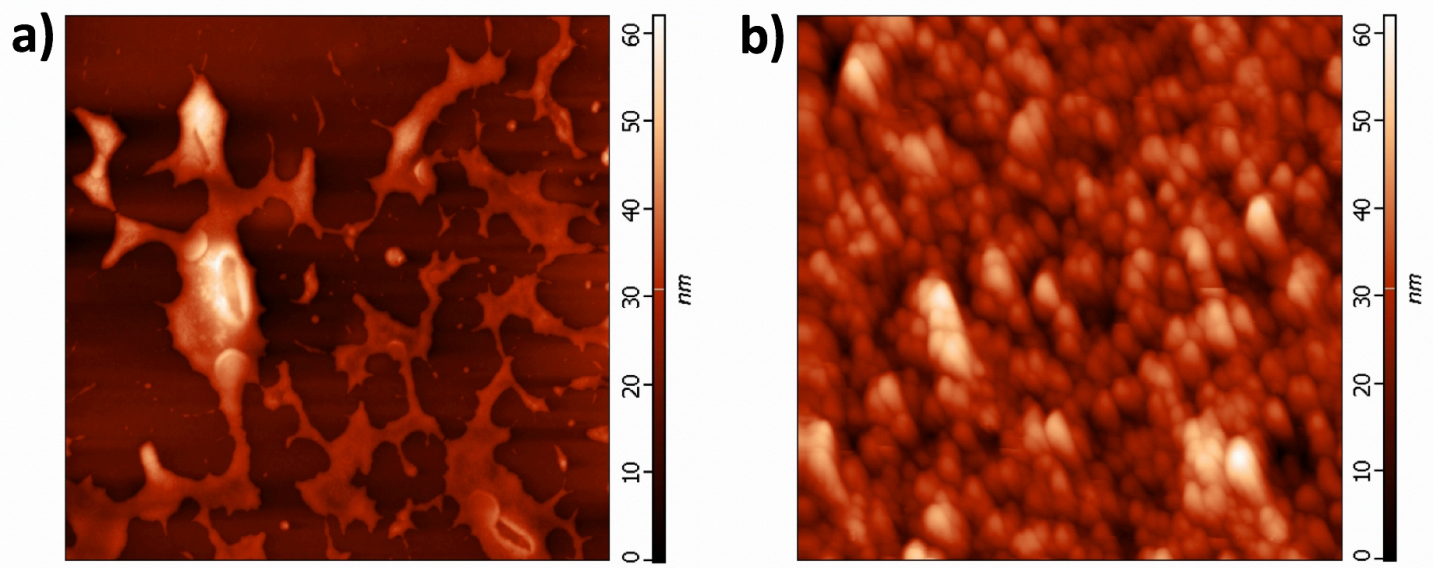

Figure 3. AFM images of (a) water-based $\mathrm{Cu}-\mathrm{NiO}_{\mathrm{x}(12.2 \%)}$ and (b) IPA-based $\mathrm{Cu}-\mathrm{NiO}_{\mathrm{x}(12.2 \%)}$ films deposited on top of $\mathrm{PTB} 7: \mathrm{PC}_{70} \mathrm{BM}$ layer.

Transmission spectra of the casted $\mathrm{NiO}_{\mathrm{x}}$ films as a function of $\mathrm{Cu}$-doping levels are shown in Figure $\mathbf{S - 4}$. The $40 \mathrm{~nm}$-thick pristine $\mathrm{NiO}_{\mathrm{x}}$ films revealed a high transmission $(>80 \%)$ in the visible region. As expected, the optical transmittance was slightly decreased with the increase of $\mathrm{Cu}$-doping level. This is attributed to the presence of defect states that are responsible for additional absorption, thus lowering the transmittance as seen before for the doped $\mathrm{TiO}_{2} \mathrm{NPs}^{43}$ Despite this decrease in transmittance, the $\mathrm{Cu}-\mathrm{NiO}_{\mathrm{x}(12.2 \%)}$ layers still owe a percentage of transmittance higher than $78 \%$ in the visible region. This allows them to function as efficient semi-transparent interfacial layers in polymer solar cells.

\subsection{Solar cell devices using $\mathrm{Cu}-\mathrm{NiO}_{\mathrm{x}}$ HTLs}

\subsubsection{Regular device structures}

In order to evaluate the potential of the $\mathrm{Cu}-\mathrm{NiO}_{\mathrm{x}(12.2 \%)}$ as HTLs, PSCs have been first studied in fullerene-based solar cells using a regular device structure with the following architecture: ITO/HTL/PTB7:PC $70 \mathrm{BM} / \mathrm{ZnO} / \mathrm{Al}$, as shown in Figure 4a. The corresponding solar cells showed poor performance with a PCE of $1.2 \%$ when compared to the reference device based on PEDOT:PSS HTL with a PCE of 7.6\%. The main losses of the devices using the $\mathrm{Cu}-\mathrm{NiO}_{\mathrm{x}(12.2 \%)} \mathrm{HTLs}$ were in $\mathrm{V}_{\mathrm{OC}}$ and FF. It has been shown that different techniques help in suppressing the interface recombination in metal oxide based HTL. ${ }^{15}$ In the present case, such losses can be induced by the hole extraction barrier at the interface due to the energy level mismatch between the $\mathrm{HOMO}$ of PTB7 and the valence band of $\mathrm{Cu}-\mathrm{NiO}_{\mathrm{x}(12.2 \%)} \mathrm{HTL}$. By using 
UPS analysis, we found indeed that the $\mathrm{Cu}-\mathrm{NiO}_{\mathrm{x}(12.2 \%)}$ layers have a low WF of only $4.47 \mathrm{eV}$ (Figure S-5). To improve the electronic properties of the $\mathrm{Cu}-\mathrm{NiO}_{\mathrm{x}(12.2 \%)} \mathrm{HTLs}$, we thus applied molecular doping with F4-TCNQ molecule that was found to tune the work function of $\mathrm{NiO}_{\mathrm{x}}$ materials. ${ }^{16}$ In our work, the molecular doping was performed by spin-coating the F4-TCNQ solution on top of $\mathrm{NiO}_{\mathrm{x}} \mathrm{HTL}$.

The UPS measurements of the $\mathrm{Cu}-\mathrm{NiO}_{\mathrm{x}(12.2 \%)}$ layers with and without F4-TCNQ are shown in Figure S-5. The WF was increased from $4.94 \mathrm{eV}$ to $5.45 \mathrm{eV}$ by increasing the F4-TCNQ concentration from 0.2 to $2 \mathrm{mg} \mathrm{mL}^{-1}$, similarly to $\mathrm{NiO}_{\mathrm{x}}$ : $\mathrm{F} 4-\mathrm{TCNQ}$ nanocomposite reported by Cheng et al. ${ }^{16}$ Consequently, solar cells using a 40 nm-thick $\mathrm{Cu}-\mathrm{NiO}_{\mathrm{x}(12.2 \%)}$ with different $\mathrm{F} 4$ TCNQ concentrations from 0.2 to $1 \mathrm{mg} \mathrm{mL}^{-1}$ were processed in order to study the impact of the WF tuning on the photovoltaic parameters of the devices. The J-V curves of the devices are shown in Figure $\mathbf{4 b}$ and the photovoltaic parameters are summarized in Table 1. An optimal performance was found for $1 \mathrm{mg} \mathrm{mL}^{-1} \mathrm{~F} 4$-TCNQ leading to a PCE of $7.4 \%$, a FF of $60 \%$, a $\mathrm{V}_{\mathrm{OC}}$ of $751 \mathrm{mV}$ and a $\mathrm{J}_{\mathrm{SC}}$ of $16.6 \mathrm{~mA} \mathrm{~cm} \mathrm{~cm}^{-2}$. This is comparable to that obtained using PEDOT:PSS HTLs with a PCE of $7.6 \%$. Further increase in the F4-TCNQ concentration causes a drop in $\mathrm{V}_{\mathrm{OC}}$ and FF. These losses could be related to the high WF $(5.45 \mathrm{eV})$ as well as the potential additional resistances generated by the F4-TCNQ layer. We also studied the impact of the HTL thickness on the device performance. The optimized $\mathrm{Cu}-\mathrm{NiO}_{\mathrm{x}(12.2 \%)}$ thickness was found at 40 $\mathrm{nm}$, as thinner layers of $15 \mathrm{~nm}$ showed less compact layer morphology, while further increase in the HTL thickness caused a decrease in efficiency mainly due to a drop in $\mathrm{J}_{\mathrm{SC}}$ (see Figure $\mathbf{S}$ 6). The later can be related to the increased absorption of the thicker $\mathrm{Cu}-\mathrm{NiO}_{\mathrm{x}} \mathrm{HTLs}$.

a)

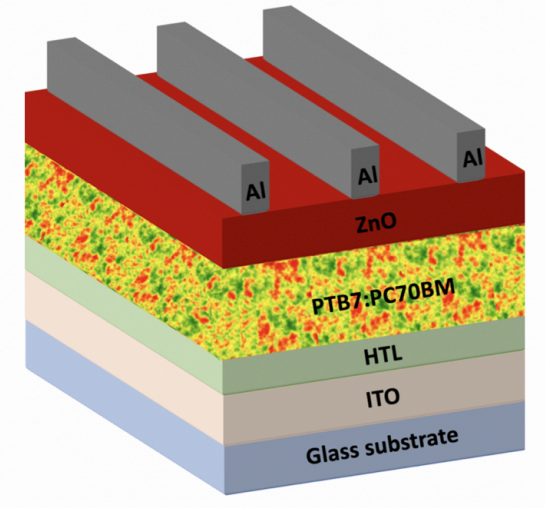

b)

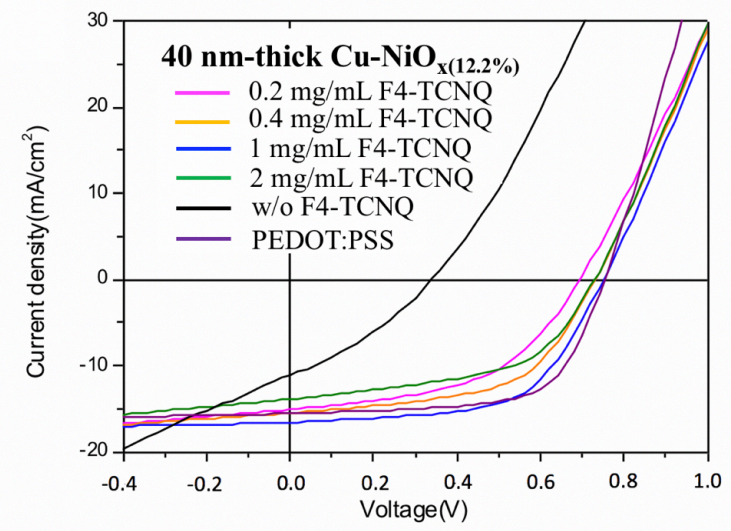

Figure 4. (a) The architecture of the studied regular device structure and (b) typical J-V curves of the PTB7:PC 70 BM-based devices using different HTLs.

$\begin{array}{lllll}{[\text { F4-TCNQ }]\left(\mathrm{mg} \mathrm{mL}^{-1}\right)} & V_{O C}(\mathrm{mV}) & \mathrm{J}_{\mathrm{SC}}(\mathrm{mA} \mathrm{cm} & \text { FF }(\%) & \text { PCE (\%) }\end{array}$

\begin{tabular}{ccccc}
\hline w/o & 340 & 11.05 & 33 & 1.2 \\
\hline 0.2 & 693 & 15 & 50 & 5.2 \\
\hline 0.4 & 730 & 15.5 & 55.2 & 6.2 \\
\hline 1 & 751 & 16.6 & 60 & 7.4 \\
\hline 2 & 729 & 13.9 & 53 & 5.3 \\
\hline PEDOT:PSS & 752 & 15.5 & 65 & 7.6 \\
\hline
\end{tabular}

Table 1. Summary of photovoltaic parameters of the PTB7:PC ${ }_{70} \mathrm{BM}$ regular-based devices using different HTLs. 


\subsubsection{Inverted device structures}

After optimizing the $\mathrm{Cu}-\mathrm{NiO}_{\mathrm{x}(12.2 \%)} \mathrm{HTLs}$ in regular device structures, these alcoholicbased $\mathrm{Cu}-\mathrm{NiO}_{\mathrm{x}(12.2 \%)}$ HTLs were used for the first time in an inverted device structure as a replacement of the classical evaporated $\mathrm{MoO}_{3}$. For such a device architecture, the non-fullerene acceptors have attracted strong attention as they possess an improved visible-NIR lightharvesting capability and good electron mobility, thus, delivering higher $\mathrm{J}_{\mathrm{SC}}$ and PCE in solar cells than fullerene acceptors. ${ }^{1}$

In this regard, we focused our studies on the inverted device structures using PBDB-T2F:IT-4F photoactive layers. The studied device architecture is ITO/ZnO/80 nm-thick PBDBT-2F:IT-4F/HTL/Ag as shown in Figure 5a. The J-V curves of the corresponding devices are presented in Figure 5b and the photovoltaic parameters are summarized in Table 2. As a reference cell, an efficiency of $11 \%$ was obtained using a 2 nm-thick evaporated $\mathrm{MoO}_{3}$ with a $62 \% \mathrm{FF}$ after post-annealing the whole device at $100{ }^{\circ} \mathrm{C}$ for 10 minutes. By replacing the evaporated $\mathrm{HTL}$ with a $40 \mathrm{~nm}$-thick molecularly doped $\mathrm{Cu}-\mathrm{NiO}_{\mathrm{x}(12.2 \%)}$, the optimized efficiency obtained was $7.92 \%$ with a FF of $53.3 \%$, a $\mathrm{V}_{\mathrm{OC}}$ of $827 \mathrm{mV}$ and a $\mathrm{J}_{\mathrm{SC}}$ of $18 \mathrm{~mA} \mathrm{~cm}^{-2}$. The lower PCE, compared to the reference cells using $\mathrm{MoO}_{x}$, is due to losses in all photovoltaic parameters indicating that the HTL is not yet fully optimized for the NFA-based solar cells.

The drops in $\mathrm{V}_{O C}$ and $\mathrm{FF}$ indicate still residual misalignments of the interface levels leading to barriers for hole extraction. For comparison, we also processed devices using modified PEDOT:PSS inks with suitable wettability properties for processing on top of polymer blend. These inks have been previously optimized for fullerene-based blends. As can be seen in Figure S-7 and Table 2, these devices show clearly lower performances compared to the devices processed with the hybrid HTLs. Indeed, even stronger losses in Voc and FF are found for PEDOT:PSS-based devices, indicating the occurrence of strong interfacial losses compared to cells using fullerene acceptors. While the performance losses in Voc and FF need further improvement in the electronic properties of the hybrid HTL, we focus in the following paragraph on the losses in $\mathrm{J}_{\mathrm{SC}}$ that may be related to optical spacer effects.
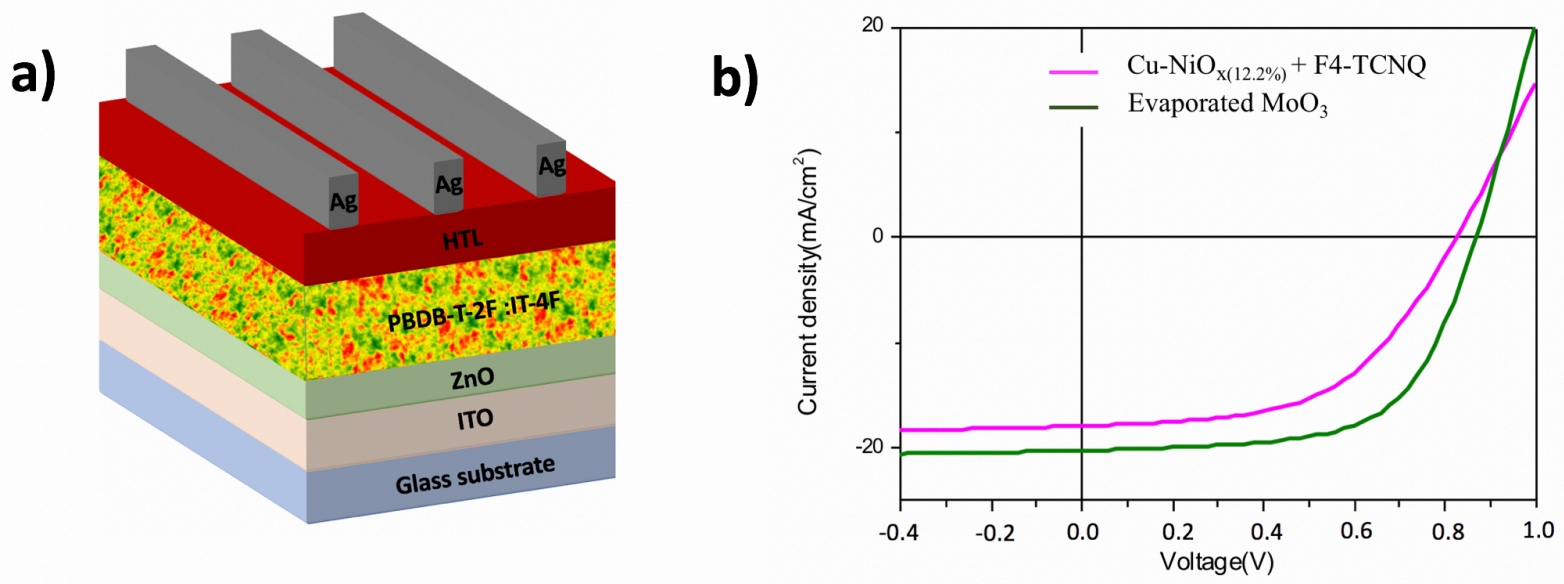

Figure 5. (a) The architecture of the studied inverted device structure and (b) The J-V curves of the PBDB-T-2F:IT-4F-based inverted device structures using different HTLs. 


\begin{tabular}{ccccc}
\hline HTL & VoC $_{\text {OmV) }}$ & $\mathbf{J}_{\text {SC }}\left(\mathbf{m A ~ \mathbf { ~ m } ^ { - 2 }}\right)$ & FF (\%) & PCE (\%) \\
\hline $2 \mathrm{~nm} \mathrm{e-MoO}_{3}$ & 871 & 20.3 & 62 & 11 \\
\hline $40 \mathrm{~nm} \mathrm{Cu}-\mathrm{NiO}_{\mathrm{x}(12.2 \%)}+\mathrm{F} 4-\mathrm{TCNQ}$ & 827 & 18 & 53.3 & 7.92 \\
\hline $40 \mathrm{~nm}$ modified PEDOT:PSS & 700 & 19 & 46.3 & 6.3 \\
\hline
\end{tabular}

Table 2. Summary of the photovoltaic parameters of the PBDB-T-2F:IT-4F based inverted devices using different HTLs.

\subsubsection{Optical spacer effects in inverted device structures}

As mentioned previously, by replacing the evaporated $\mathrm{MoO}_{3}$ with the solutionprocessed $\mathrm{Cu}-\mathrm{NiO}_{\mathrm{x}(12.2 \%)} \mathrm{HTL}$, losses in $\mathrm{J}_{\mathrm{SC}}$ of around $10 \%$ are observed. It is well known that metal oxides such as $\mathrm{ZnO}$ can introduce optical spacer effect in polymer solar cells that modifies strongly the light distribution inside the cell and thus the intensity of the photocurrent density. ${ }^{35,42}$ While these optical spacer effects have been only described in devices using regular structures, it is possible that the $\mathrm{J}_{\mathrm{SC}}$ losses in inverted device structures, as used here, may be also related to such effects. In order to study the optical effects more in details, the photonic absorption inside the photoactive layer as function of both the photoactive layer and HTL thickness was investigated using a transfer matrix method. ${ }^{42}$ The device structure used for the calculation was ITO/ZnO/PBDB-T-2F:IT-4F/Cu-NiO ${ }_{x(12.2 \%)}+\mathrm{F} 4-\mathrm{TCNQ} / \mathrm{Ag}$. The polymer blend and the HTL thicknesses were varied from 0 to $300 \mathrm{~nm}$ and 0 to $70 \mathrm{~nm}$, respectively, while the thicknesses of the other layers were kept constant $(150 \mathrm{~nm}$ for the ITO layer, $15 \mathrm{~nm}$ for the $\mathrm{ZnO}$ layer, and $100 \mathrm{~nm}$ for the $\mathrm{Ag}$ layer). The optical indices of ITO, $\mathrm{ZnO}$ and Ag were taken from literature ${ }^{42,44}$ while the optical indices of PBDB-T-2F:IT-4F and $\mathrm{Cu}-\mathrm{NiO}_{\mathrm{x}(12.2 \%)}$ layers were determined by spectroscopic ellipsometry (SE) (see the Experimental Section and Figure S-8). Figure 6a shows the total number of photons absorbed inside the photoactive layer as a function of the photoactive layer thickness for different $\mathrm{Cu}-\mathrm{NiO}_{\mathrm{x}(12.2 \%)}$ thicknesses. Two maxima appear in the absorption curve, which are related to interferential phenomena occurring in the thin film stacks. ${ }^{44,35,45}$

The first maximum corresponds to blend thicknesses ranging from 50 to $90 \mathrm{~nm}$ with the exact position of each maximum depending on the $\mathrm{Cu}-\mathrm{NiO}_{\mathrm{x}}$ layer thickness. The second maximum is broader with photoactive layer thicknesses ranging from 170 to $250 \mathrm{~nm}$. These simulations reveal that, for thin photoactive layers, the $\mathrm{Cu}-\mathrm{NiO}_{\mathrm{x}}$-based HTLs always lead to a reduction of light absorption inside the active layer compared to solar cells processed without any HTL. In contrast, using thick blend layers, light absorption is almost unchanged as long as the HTL is not surpassing 40-50 $\mathrm{nm}$ range. This finding is identical to solar cells using the regular device structures with $\mathrm{ZnO}$ or aluminum-doped $\mathrm{ZnO}$ as optical spacers. ${ }^{42,35}$ Here, the solar cells using $\mathrm{Cu}-\mathrm{NiO}_{\mathrm{x}(12.2 \%)} \mathrm{HTL}$ have $80 \mathrm{~nm}$-thick photoactive layers that were optimized for the ultrathin $\mathrm{MoO}_{3} \mathrm{HTL}$. This is comparable to the situation of the red curve in Figure 6a, considering that devices using a $2 \mathrm{~nm}$-thick $\mathrm{MoO}_{3}$ have almost equivalent absorption to those processed without any HTL. The use of a $40 \mathrm{~nm}$-thick $\mathrm{Cu}-\mathrm{NiO}_{\mathrm{x}(12.2 \%)} \mathrm{HTL}$ reduced strongly the amount of the absorbed light in the photoactive layer by approximately $10-15 \%$, as shown on the vertical red dotted line as eye guide. By considering these calculations, we indeed find the corresponding losses in $\mathrm{J}_{\mathrm{SC}}$ for the devices fabricated with $\mathrm{Cu}-\mathrm{NiO}_{\mathrm{x}(12.2 \%)}\left(18 \mathrm{~mA} \mathrm{~cm}^{-2}\right)$ when compared to the reference cells done with $\mathrm{MoO}_{3}$ generating $20.3 \mathrm{~mA} \mathrm{~cm}^{-2}$. These calculations allow also to discuss the most suitable conditions for the developed $\mathrm{Cu}-\mathrm{NiO}_{\mathrm{x}(12.2 \%)}$ : $\mathrm{F} 4-\mathrm{TCNQ}$ bilayers used 
in inverted device structures. By considering a $40 \mathrm{~nm}$-thick $\mathrm{Cu}-\mathrm{NiO}_{\mathrm{x}(12.2 \%)} \mathrm{HTL}$, the photoactive layer should be at least $180 \mathrm{~nm}$ in order to limit the optical losses.

As it was shown recently, the use of optical spacers allows also to modify the color of polymer solar cells. ${ }^{35}$ Indeed, the HTLs not only modify the amount of light absorbed inside the active layer but also determine the light reflection of the solar cell, thus affecting the color of the devices. To estimate the potential of the $\mathrm{Cu}-\mathrm{NiO}_{x}$ optical spacers in generating colored polymer solar cells, we calculated the color coordinates of the devices in the reflection mode as function of the photoactive layer and $\mathrm{Cu}-\mathrm{NiO}_{\mathrm{x}}$ thicknesses. Thus, for a $40 \mathrm{~nm}$-thick $\mathrm{Cu}-\mathrm{NiO}_{\mathrm{x}(12.2 \%)} \mathrm{HTL}$, the color coordinates corresponding to the reflected light were calculated for photoactive layer thicknesses ranging between 80 and $250 \mathrm{~nm}$. Figure $\mathbf{6 b}$ is a chromaticity diagram showing a comparison between the calculated and the measured color coordinates of three different solar cells $(\mathrm{B}, \mathrm{G}$ and $\mathrm{P})$ with different blend thicknesses $(80,180$ and $250 \mathrm{~nm}$, respectively). One can first notice that, as expected, the color of the devices can be strongly tuned by adjusting the photoactive layer thickness, thus comparable to solar cells using regular device structure having $\mathrm{ZnO}$ electron transport layers. For an $80 \mathrm{~nm}$-thick photoactive layer, the devices have a blue color. They become successively green and pink when the active layer thickness was increased to 180 and $250 \mathrm{~nm}$, respectively. Importantly, very good agreements were found between the color coordinates obtained from simulations with the different measured colors of the three solar cells. Thus, these results show that a large palette of colors can be produced with this technique, making fine-tuning of the color possible via adjusting the $\mathrm{Cu}-\mathrm{NiO}_{\mathrm{x}}$ optical spacer and the photoactive layer thicknesses, thanks to the control in the light absorption amount. 

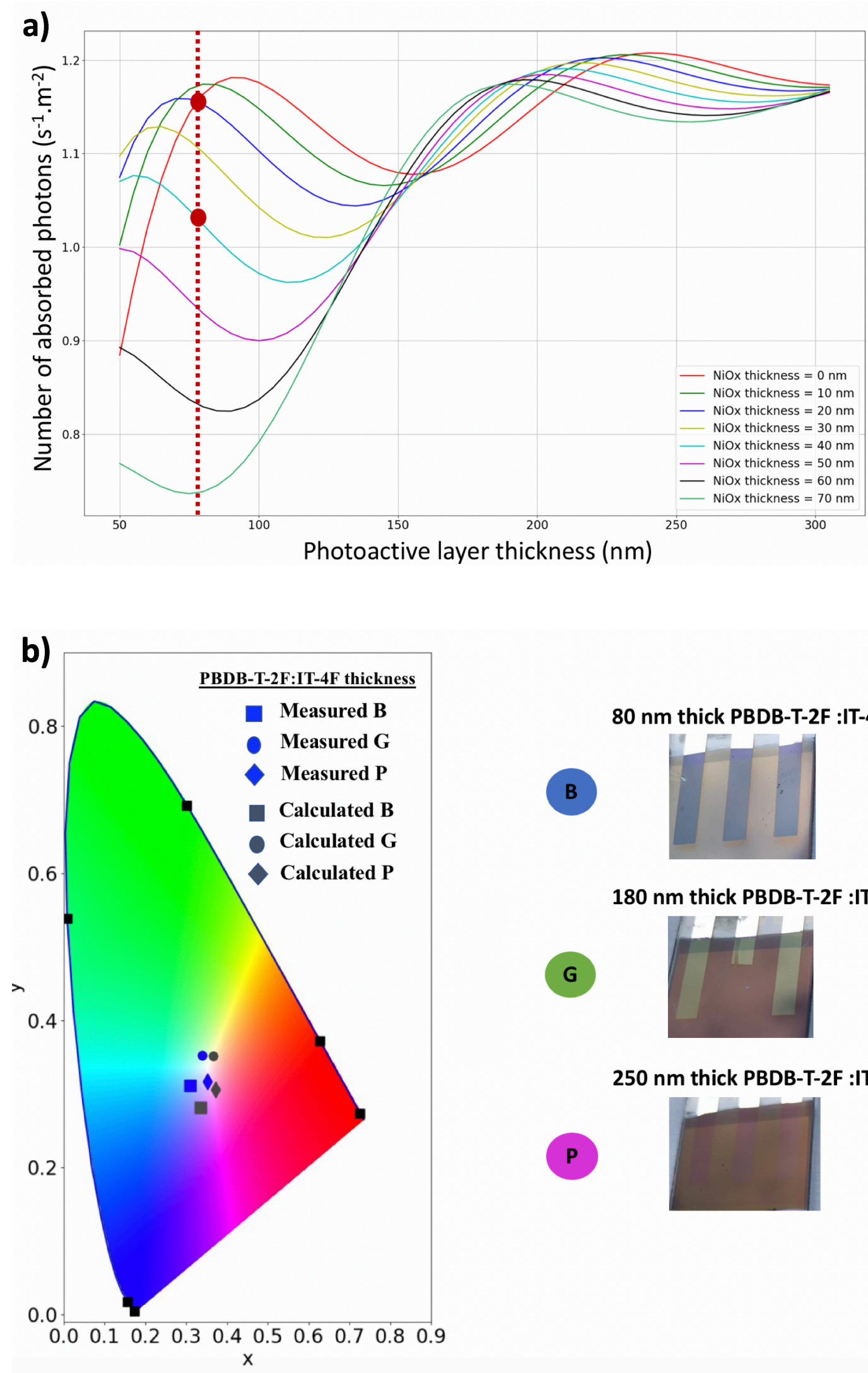

$80 \mathrm{~nm}$ thick PBDB-T-2F :IT-4F

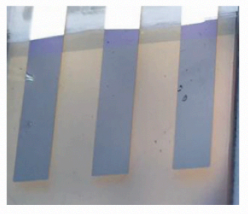

$180 \mathrm{~nm}$ thick PBDB-T-2F :IT-4F
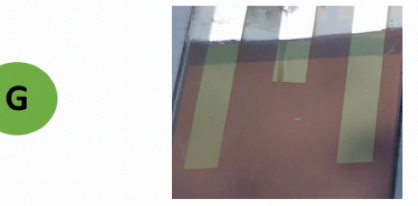

250 nm thick PBDB-T-2F :IT-4F

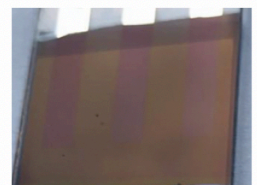

Figure 6. (a) The theoretical total number of photons absorbed inside the PBDB-T-2F:IT-4F photoactive layer as a function of photoactive layer thickness for different $\mathrm{Cu}-\mathrm{NiO}_{\mathrm{x}(12.2 \%)}$ thicknesses. (b) Measured (blue dots) and calculated (grey dots) color coordinates for the three experimental Blue, Green and Pink solar cells (left) and photograph images of the corresponding cells (right). 


\section{Conclusion}

Nickel oxide nanoparticles in alcoholic solutions were developed in this work for processing hole transport layers and were applied to non-fullerene acceptor-based solar cells using inverted device structures. We show that copper doping of $\mathrm{NiO}_{\mathrm{x}}$ nanoparticles is beneficial to reach aggregate-free solution suitable for processing the HTL on top of photoactive layers. Further doping of these nanoparticles with the organic electron acceptor F4-TCNQ was necessary to optimize the work function of the HTL for efficient hole extraction. Solar cells using normal device structures revealed that such hybrid HTL can be processed up to $45 \mathrm{~nm}$ without inducing electric losses due to optimized work function and high conductivity. Processing the hybrid HTLs on top of polymer blends based on IT-4F and PBDB-T-2F led to solar cells with promising efficiencies up to $7.9 \%$, while further work function optimization is needed to reach fully optimized solution-processed organic-inorganic $\mathrm{Cu}-\mathrm{NiO}_{\mathrm{x}}$ nanoparticles for $\mathrm{NFA}$-based solar cells using inverted device structure. We also demonstrated for the first time that the use of the hybrid HTL in the inverted device structure of polymer solar cells allows for color tuning over a large palette using optical spacer effects. Our future work will focus on the optimization of the work function and transport properties of the organic-inorganic doped $\mathrm{NiO}_{\mathrm{x}} \mathrm{HTL}$ by combining 2D-materials such as graphene oxide to generate highly efficient HTLs for fully solution-processed solar cells using NFAs with improved air stability.

\section{Experimental Section}

Synthesis of Highly soluble $\mathrm{NiO}_{\mathbf{x}}$ NPs: All the materials were purchased from Sigma Aldrich unless specified elsewhere. $\mathrm{NiO}_{\mathrm{x}} \mathrm{NPs}$ were prepared by a chemical precipitation method according to a previous report. ${ }^{18}$ Typically, 0.05 mole of $\mathrm{Ni}\left(\mathrm{NO}_{3}\right)_{2} \cdot 6 \mathrm{H}_{2} \mathrm{O}$ were dispersed in $100 \mathrm{~mL}$ deionized water. A dark green solution was obtained. Under continuous magnetic stirring, the $\mathrm{pH}$ of the solution was adjusted to 10 by the dropwise addition of $10 \mathrm{M}$ $\mathrm{NaOH}$ aqueous solution. The $\mathrm{pH}$ value was measured by a $\mathrm{pH}$ meter (Hanna HI $8417 \mathrm{pH}$ meter). After stirring for 10 minutes, the green colloidal precipitate was washed twice by deionized water using centrifugation and dried at $80{ }^{\circ} \mathrm{C}$ overnight. To ensure a complete calcination, the obtained green solid was ground to finer powder using a pestle and a mortar, then calcined at $270{ }^{\circ} \mathrm{C}$ for 2 hours to yield a black powder. For the $\mathrm{Cu}-\mathrm{NiO}_{\mathrm{x}} \mathrm{NPs}$, the same procedure was followed. The only difference is the addition of the $\mathrm{Cu}\left(\mathrm{NO}_{3}\right)_{2} \cdot \mathrm{xH}_{2} \mathrm{O}$ precursor in the initial solution at various molar ratios (from 2 to $20 \%$ ).

Preparation of the $\mathrm{NiO}_{\mathrm{x}}$ solutions: $\mathrm{NiO}_{\mathrm{x}} \mathrm{NPs}$ were dispersed in water to the desired concentration. Then, the solution was transferred to IPA solvent and dispersed using a probe ultrasonication until obtaining an aggregate-free solution.

Preparation of the $\mathrm{ZnO}$ solutions: $\mathrm{ZnO}$ NPs were prepared as published elsewhere. ${ }^{46,47}$ The cluster-free $\mathrm{ZnO}$ nanoparticle solution of $5 \mathrm{mg} \mathrm{mL}^{-1}$ was prepared by transferring the assynthesized $\mathrm{ZnO}$ nanoparticles from methanol into isopropanol mixed with ethanolamine $(0.2$ vol.\%).

Characterization Methods: The $\mathrm{NiO}_{\mathrm{x}}$ NCs were characterized by HR-TEM (JEOL 3010, acceleration voltage of $300 \mathrm{kV}$ ). The samples were prepared by drop-casting a diluted isopropanol solution of $\mathrm{NiO}_{\mathrm{x}} \mathrm{NCs}$ onto a carbon-coated copper grid. UV-vis absorption of the $\mathrm{NiO}_{\mathrm{x}} \mathrm{NCs}$ in solution and on films were recorded using a Varian CARY 50 spectrophotometer. 
Size distribution of the NCs within the solution was determined by DLS using a NanoZetaSizer from Malvern. Crystallinity of the $\mathrm{NiO}_{x} \mathrm{NCs}$ was measured by XRD using an INEL with a linear detector. AFM was realized using a NTEGRA Prima of the brand NT-MDT in taping mode to study the quality of the $\mathrm{NiO}_{\mathrm{x}} \mathrm{NCs}$ layers. Layer thicknesses were determined using a mechanical profilometer. Photoemission spectroscopy using UV (UPS, HeI $21.2 \mathrm{eV}$ ) and X-ray (XPS, monochromatized Al Ka $1486.7 \mathrm{eV}$ ) light sources were performed at Linkoping University in Sweden.

Optical Simulations of the Solar Cells: Ellipsometry has been used to extract the optical indices of $\mathrm{Cu}-\mathrm{NiO}_{\mathrm{x}}$ thin films. The measurements have been performed for wavelengths ranging between 380 and $1000 \mathrm{~nm}$ using a Semilab rotating compensator ellipsometer equipped with a microspot which focuses the beam on a very small area of the sample (a circle with a diameter of $100 \mu \mathrm{m})$.

The layers were coated on glass substrates. SEA software (Semilab company) was used to fit the SE measurements of $\tan (\Psi)$ and $\cos (\Delta)$ and extract the optical indices $n(\lambda)$ and $k(\lambda)$ of the materials. The dielectric functions $\varepsilon=\varepsilon_{1}+i^{*} \varepsilon_{2}$ of PBDB-T-2F:IT-4F have been fitted with Gaussian model that is adequate for the parameterization of the optical functions of amorphous thin films in the interband region. ${ }^{48}$ The dielectric functions of $\mathrm{Cu}-\mathrm{NiO}_{\mathrm{x}(12.2 \%)}$ have been fitted with a Gauss-Sellmeyer model in order to take into account both the dielectric and the absorbing character of this material. The optical indices of PBDB-T-2F:IT-4F and $\mathrm{Cu}-\mathrm{NiO}_{\mathrm{x}(12.2 \%)}$ are shown in Figure S-8. While the optical indices of ITO, $\mathrm{ZnO}$ and $\mathrm{Ag}$ were taken from literature. ${ }^{42,44}$ The CIE xyY (1931) model has been employed for the color prediction of the polymer solar cells. This model allows calculating the normalized color coordinates $(x, y)$ of solar cells from their reflection spectra by considering the human eye sensitivity. Using the optical indices of the materials as input parameters, the reflection spectra of the solar cells have been calculated using a transfer matrix method. ${ }^{45}$ The reflection spectra of the cells were carried out using a Perkin Elmer spectrophotometer Lambda 950.

Solar Cell Fabrication: The organic-BHJ solar cells were prepared following several steps. First, the ITO substrates $\left(15 \Omega \mathrm{sq}^{-1}\right)$ were cleaned by deionized water, acetone, ethanol, and isopropanol with ultrasonication. Then, the pre-cleaned ITO substrates were exposed to UVozone treatment for $15 \mathrm{~min}$ to reform the surface. In the case of regular device structures, a thin layer of PEDOT:PSS (Heraeus, CLEVIOS PVP AI 4083) was spin-coated on the pre-cleaned ITO substrates at a speed of $3500 \mathrm{rpm}$ for $60 \mathrm{~s}$ followed by heating on a hotplate at $140{ }^{\circ} \mathrm{C}$ for 20 min to obtain a film thickness of $\approx 40 \mathrm{~nm}$. The $\mathrm{NiO}_{\mathrm{x}}$ HTLs were spin-coated at $2500 \mathrm{rpm}$ for $60 \mathrm{~s}$ from different concentrations (10 to $\left.30 \mathrm{mg} \mathrm{mL}^{-1}\right)$ to obtain different film thicknesses. These $\mathrm{NiO}_{\mathrm{x}}$ films were then annealed on a hot plate in air at $80^{\circ} \mathrm{C}$ for $10 \mathrm{~min}$. A solution of F4-TCNQ (Ossilla) with different concentrations (from 0.2 to $2 \mathrm{mg} \mathrm{mL}^{-1}$ ) was spin-coated with the same speed and annealed at $80{ }^{\circ} \mathrm{C}$ for $30 \mathrm{~min}$. The substrates were then transferred into a nitrogenfilled glovebox. The PTB7:PC ${ }_{70} \mathrm{BM}$ blend solution was prepared from the weight ratio of 1:1.5 and a total concentration of $25 \mathrm{mg} \mathrm{mL}^{-1}$ in chlorobenzene with $0.3 \mathrm{vol} \% 1,8$-diiodooctane processing additive. After stirring overnight at $60^{\circ} \mathrm{C}$, the BHJ thin films $(90 \mathrm{~nm})$ were obtained from spin-coating the solution at $1800 \mathrm{rpm}$ for $120 \mathrm{~s}$. The active layers were then transferred into high vacuum for overnight. ZnO NCs were processed by spin-coating a $5 \mathrm{mg} \mathrm{mL}^{-1}$ solution on top of the active layers at $1500 \mathrm{rpm}$ for $60 \mathrm{~s}$ followed by annealing for $2 \mathrm{~min}$ at $80^{\circ} \mathrm{C}$. The top Al metal electrode $\left(100 \mathrm{~nm}\right.$ ) was thermally evaporated at $1 \times 10^{-6}$ Torr pressure through a shadow mask with a device area of $0.27 \mathrm{~cm}^{2}$. 
For the inverted device structures, $1 \mathrm{wt} . \% \mathrm{ZnO}$ (Avantama) was spin-coated on top of the precleaned ITO substrates at $5000 \mathrm{rpm}$ for $60 \mathrm{~s}$ then annealed at $120{ }^{\circ} \mathrm{C}$ for $10 \mathrm{~min}$ in air. The PBDB-T-2F:IT-4F solution was prepared from a weight ratio 1:1 and a total concentration of $20 \mathrm{mg} \mathrm{mL}^{-1}$ in o-xylene. After stirring overnight at room temperature, the active layers were prepared by spin-casting the ink at $2200 \mathrm{rpm}$ for $2 \mathrm{~min}$ (without annealing). A $2 \mathrm{~nm}$-thick $\mathrm{MoO}_{3}$ layer and a $100 \mathrm{~nm}$-thick silver layer were then thermally evaporated onto the surface of the active layer at $2 \times 10^{-6}$ Torr pressure through a shadow mask. For each device configuration, a total of six cells were measured. The current density-voltage $(\mathrm{J}-\mathrm{V})$ characteristics of the devices were measured using a Keithley 238 Source Measure Unit. Solar cell performance was measured using a Newport classe AAA 1.5 Global solar simulator (Oriel Sol3ATM model $\mathrm{n}^{\circ}$ 94043A) with an irradiation intensity of $100 \mathrm{~mW} \mathrm{~cm}^{-2}$. The light intensity was determined with a Si reference cell (Newport Company, Oriel $n^{\circ}$ 94043A) calibrated by National Renewable Energy Laboratory (NREL).

\section{Conflicts of interest}

There are no conflicts to declare.

\section{Acknowledgments}

The authors thank Alain Ranguis, Damien Chaudanson and Vasile Heresanu from CINaM laboratory for their assistance in the use of AFM, TEM and XRD facilities. They also acknowledge Igor Ozerov and Frédéric Bedu for the profilometer measurements performed at the PLANETE CT PACA cleanroom facility.

\section{References}

1 Q. Liu, Y. Jiang, K. Jin, J. Qin, J. Xu, W. Li, J. Xiong, J. Liu, Z. Xiao, K. Sun, S. Yang, X. Zhang and L. Ding, 18\% Efficiency organic solar cells, Sci. Bull., 2020, 65, 272-275.

2 R. Po, C. Carbonera, A. Bernardi and N. Camaioni, The role of buffer layers in polymer solar cells, Energy Environ. Sci., 2011, 4, 285-310.

3 A. N. Bartynski, C. Trinh, A. Panda, K. Bergemann, B. E. Lassiter, J. D. Zimmerman, S. R. Forrest and M. E. Thompson, A Fullerene-Based Organic Exciton Blocking Layer with High Electron Conductivity, Nano Lett., 2013, 13, 3315-3320.

4 M. C. Scharber, D. Mühlbacher, M. Koppe, P. Denk, C. Waldauf, A. J. Heeger and C. J. Brabec, Design Rules for Donors in Bulk-Heterojunction Solar Cells-Towards 10 \% Energy-Conversion Efficiency, Adv. Mater., 2006, 18, 789-794.

5 Y. Xia, K. Sun and J. Ouyang, Solution-Processed Metallic Conducting Polymer Films as Transparent Electrode of Optoelectronic Devices, Adv. Mater., 2012, 24, 2436-2440.

6 Q. Li, J. Yang, S. Chen, J. Zou, W. Xie and X. Zeng, Highly Conductive PEDOT:PSS Transparent Hole Transporting Layer with Solvent Treatment for High Performance Silicon/Organic Hybrid Solar Cells, Nanoscale Res. Lett., 2017, 12, 506.

7 Y. Meng, Z. Hu, N. Ai, Z. Jiang, J. Wang, J. Peng and Y. Cao, Improving the Stability of Bulk Heterojunction Solar Cells by Incorporating pH-Neutral PEDOT:PSS as the Hole Transport Layer, ACS Appl. Mater. Interfaces, 2014, 6, 5122-5129. 
8 W.-H. Baek, M. Choi, T.-S. Yoon, H. H. Lee and Y.-S. Kim, Use of fluorine-doped tin oxide instead of indium tin oxide in highly efficient air-fabricated inverted polymer solar cells, Appl. Phys. Lett., 2010, 96, 133506.

9 Y.-J. Cheng, C.-H. Hsieh, Y. He, C.-S. Hsu and Y. Li, Combination of Indene-C60 Bis-Adduct and Cross-Linked Fullerene Interlayer Leading to Highly Efficient Inverted Polymer Solar Cells, J. Am. Chem. Soc., 2010, 132, 17381-17383.

10S. K. Hau, H.-L. Yip, H. Ma and A. K.-Y. Jen, High performance ambient processed inverted polymer solar cells through interfacial modification with a fullerene self-assembled monolayer, Appl. Phys. Lett., 2008, 93, 233304.

$11 \mathrm{~F}$. Wang, Z. Tan and Y. Li, Solution-processable metal oxides/chelates as electrode buffer layers for efficient and stable polymer solar cells, Energy Environ. Sci., 2015, 8, 1059-1091.

12 D. Ouyang, Z. Huang and W. C. H. Choy, Solution-Processed Metal Oxide Nanocrystals as Carrier Transport Layers in Organic and Perovskite Solar Cells, Adv. Funct. Mater., 2019, 29, 1804660.

13 D. Ouyang, J. Xiao, F. Ye, Z. Huang, H. Zhang, L. Zhu, J. Cheng and W. C. H. Choy, Strategic Synthesis of Ultrasmall $\mathrm{NiCO}_{2} \mathrm{O}_{4}$ NPs as Hole Transport Layer for Highly Efficient Perovskite Solar Cells, Adv. Energy Mater., 2018, 8, 1702722.

14 B. Yang, D. Ouyang, Z. Huang, X. Ren, H. Zhang and W. C. H. Choy, Multifunctional Synthesis Approach of In:CuCrO ${ }_{2}$ Nanoparticles for Hole Transport Layer in High-Performance Perovskite Solar Cells, Adv. Funct. Mater., 2019, 29, 1902600.

15Z. Huang, D. Ouyang, R. Ma, W. Wu, V. A. L. Roy and W. C. H. Choy, A General Method: Designing a Hypocrystalline Hydroxide Intermediate to Achieve Ultrasmall and Well-Dispersed Ternary Metal Oxide for Efficient Photovoltaic Devices, Adv. Funct. Mater., 2019, 29, 1904684.

16 J. Cheng, X. Ren, H. L. Zhu, J. Mao, C. Liang, J. Zhuang, V. A. L. Roy and W. C. H. Choy, Pre- and post-treatments free nanocomposite based hole transport layer for high performance organic solar cells with considerably enhanced reproducibility, Nano Energy, 2017, 34, 76-85.

17Z. Huang, G. Natu, Z. Ji, M. He, M. Yu and Y. Wu, Probing the Low Fill Factor of NiO p-Type DyeSensitized Solar Cells, J. Phys. Chem. C, 2012, 116, 26239-26246.

18 F. Jiang, W. C. H. Choy, X. Li, D. Zhang and J. Cheng, Post-treatment-Free Solution-Processed Nonstoichiometric $\mathrm{NiO}(\mathrm{x})$ Nanoparticles for Efficient Hole-Transport Layers of Organic Optoelectronic Devices, Adv. Mater. Deerfield Beach Fla, 2015, 27, 2930-2937.

19 M. D. Irwin, D. B. Buchholz, A. W. Hains, R. P. H. Chang and T. J. Marks, p-Type semiconducting nickel oxide as an efficiency-enhancing anode interfacial layer in polymer bulk-heterojunction solar cells, Proc. Natl. Acad. Sci. U. S. A., 2008, 105, 2783-2787.

20S.-Y. Park, H.-R. Kim, Y.-J. Kang, D.-H. Kim and J.-W. Kang, Organic solar cells employing magnetron sputtered p-type nickel oxide thin film as the anode buffer layer, Sol. Energy Mater. Sol. Cells, 2010, 94, 2332-2336.

21Z. Yi Wang, S.-H. Lee, D.-H. Kim, J.-H. Kim and J.-G. Park, Effect of NiOx thin layer fabricated by oxygen-plasma treatment on polymer photovoltaic cell, Sol. Energy Mater. Sol. Cells, 2010, 94, 1591-1596.

22 S. Seo, I. J. Park, M. Kim, S. Lee, C. Bae, H. S. Jung, N.-G. Park, J. Y. Kim and H. Shin, An ultra-thin, un-doped $\mathrm{NiO}$ hole transporting layer of highly efficient (16.4\%) organic-inorganic hybrid perovskite solar cells, Nanoscale, 2016, 8, 11403-11412.

23 A. Garcia, G. C. Welch, E. L. Ratcliff, D. S. Ginley, G. C. Bazan and D. C. Olson, Improvement of Interfacial Contacts for New Small-Molecule Bulk-Heterojunction Organic Photovoltaics, Adv. Mater., 2012, 24, 5368-5373.

24 S. Yoon and D.-W. Kang, Solution-processed nickel oxide hole transport layer for highly efficient perovskite-based photovoltaics, Ceram. Int., 2018, 44, 9347-9352.

$25 \mathrm{~K}$. Zilberberg, J. Meyer and T. Riedl, Solution processed metal-oxides for organic electronic devices, J. Mater. Chem. C, 2013, 1, 4796-4815. 
26 H. Zhang, J. Cheng, D. Li, F. Lin, J. Mao, C. Liang, A. K.-Y. Jen, M. Grätzel and W. C. H. Choy, Toward All Room-Temperature, Solution-Processed, High-Performance Planar Perovskite Solar Cells: A New Scheme of Pyridine-Promoted Perovskite Formation, Adv. Mater., 2017, 29, 1604695.

27 X. Yin, P. Chen, M. Que, Y. Xing, W. Que, C. Niu and J. Shao, Highly Efficient Flexible Perovskite Solar Cells Using Solution-Derived NiOx Hole Contacts, ACS Nano, 2016, 10, 3630-3636.

28 J. Ciro, D. Ramírez, M. A. Mejía Escobar, J. F. Montoya, S. Mesa, R. Betancur and F. Jaramillo, SelfFunctionalization Behind a Solution-Processed NiOx Film Used As Hole Transporting Layer for Efficient Perovskite Solar Cells, ACS Appl. Mater. Interfaces, 2017, 9, 12348-12354.

29 H. Zhang, J. Cheng, F. Lin, H. He, J. Mao, K. S. Wong, A. K.-Y. Jen and W. C. H. Choy, Pinhole-Free and Surface-Nanostructured NiOx Film by Room-Temperature Solution Process for HighPerformance Flexible Perovskite Solar Cells with Good Stability and Reproducibility, ACS Nano, 2016, 10, 1503-1511.

30 J. Cheng, H. Zhang, Y. Zhao, J. Mao, C. Li, S. Zhang, K. S. Wong, J. Hou and W. C. H. Choy, SelfAssembled Quasi-3D Nanocomposite: A Novel p-Type Hole Transport Layer for High Performance Inverted Organic Solar Cells, Adv. Funct. Mater., 2018, 28, 1706403.

$31 \mathrm{~J}$. W. Jung, C.-C. Chueh and A. K.-Y. Jen, A Low-Temperature, Solution-Processable, Cu-Doped Nickel Oxide Hole-Transporting Layer via the Combustion Method for High-Performance Thin-Film Perovskite Solar Cells, Adv. Mater., 2015, 27, 7874-7880.

$32 \mathrm{Q}$. He, K. Yao, X. Wang, X. Xia, S. Leng and F. Li, Room-Temperature and Solution-Processable CuDoped Nickel Oxide Nanoparticles for Efficient Hole-Transport Layers of Flexible Large-Area Perovskite Solar Cells, ACS Appl. Mater. Interfaces, 2017, 9, 41887-41897.

33 J.-Y. Jeng, M.-W. Lin, Y.-J. Hsu, T.-C. Wen and T.-F. Guo, The Roles of Poly(Ethylene Oxide) Electrode Buffers in Efficient Polymer Photovoltaics, Adv. Energy Mater., 2011, 1, 1192-1198.

34 F. Guillain, J. Endres, L. Bourgeois, A. Kahn, L. Vignau and G. Wantz, Solution-Processed p-Dopant as Interlayer in Polymer Solar Cells, ACS Appl. Mater. Interfaces, 2016, 8, 9262-9267.

35 M. Gaceur, S. B. Dkhil, D. Duché, F. Bencheikh, J.-J. Simon, L. Escoubas, M. Mansour, A. Guerrero, G. Garcia-Belmonte, X. Liu, M. Fahlman, W. Dachraoui, A. K. Diallo, C. Videlot-Ackermann, O. Margeat and J. Ackermann, Ligand-Free Synthesis of Aluminum-Doped Zinc Oxide Nanocrystals and their Use as Optical Spacers in Color-Tuned Highly Efficient Organic Solar Cells, Adv. Funct. Mater., 2016, 26, 243-253.

36 A. K. K. Kyaw, D. H. Wang, D. Wynands, J. Zhang, T.-Q. Nguyen, G. C. Bazan and A. J. Heeger, Improved Light Harvesting and Improved Efficiency by Insertion of an Optical Spacer (ZnO) in Solution-Processed Small-Molecule Solar Cells, Nano Lett., 2013, 13, 3796-3801.

37 R. D. Shannon, Revised effective ionic radii and systematic studies of interatomic distances in halides and chalcogenides, Acta Crystallogr. A, 1976, 32, 751-767.

$38 \mathrm{M}$. Singh, M. Goyal and K. Devlal, Size and shape effects on the band gap of semiconductor compound nanomaterials, J. Taibah Univ. Sci., 2018, 12, 470-475.

39 T. N. Ramesh and P. V. Kamath, Synthesis of nickel hydroxide: Effect of precipitation conditions on phase selectivity and structural disorder, J. Power Sources, 2006, 156, 655-661.

40 A. Savva, M. Neophytou, C. Koutsides, K. Kalli and S. A. Choulis, Synergistic effects of buffer layer processing additives for enhanced hole carrier selectivity in inverted Organic Photovoltaics, Org. Electron., 2013, 14, 3123-3130.

41 M. Wagner, C. D. O'Connell, D. G. Harman, R. Sullivan, A. Ivaska, M. J. Higgins and G. G. Wallace, Synthesis and optimization of PEDOT:PSS based ink for printing nanoarrays using Dip-Pen Nanolithography, Synth. Met., 2013, 181, 64-71.

42 S. B. Dkhil, D. Duché, M. Gaceur, A. K. Thakur, F. B. Aboura, L. Escoubas, J.-J. Simon, A. Guerrero, J. Bisquert, G. Garcia-Belmonte, Q. Bao, M. Fahlman, C. Videlot-Ackermann, O. Margeat and J. Ackermann, Interplay of Optical, Morphological, and Electronic Effects of ZnO Optical Spacers in Highly Efficient Polymer Solar Cells, Adv. Energy Mater., 2014, 4, 1400805. 
43 V. R. Akshay, B. Arun, G. Mandal and M. Vasundhara, Visible range optical absorption, Urbach energy estimation and paramagnetic response in $\mathrm{Cr}$-doped TiO2 nanocrystals derived by a sol-gel method, Phys. Chem. Chem. Phys., 2019, 21, 12991-13004.

44 D. Duché, E. Drouard, JJ. Simon, L. Escoubas, Ph. Torchio, J. Le Rouzo and S. Vedraine, Light harvesting in organic solar cells, Sol. Energy Mater. Sol. Cells, 2011, 95, S18-S25.

45 D. Duché, F. Bencheikh, S. B. Dkhil, M. Gaceur, N. Berton, O. Margeat, J. Ackermann, J. J. Simon and L. Escoubas, Optical performance and color investigations of hybrid solar cells based on P3HT:ZnO, PCPDTBT:ZnO, PTB7:ZnO and DTS(PTTh2)2:ZnO, Sol. Energy Mater. Sol. Cells, 2014, 126, 197-204.

46 G. E. Jellison and F. A. Modine, Parameterization of the optical functions of amorphous materials in the interband region, Appl. Phys. Lett., 1998, APLCLASS2019, 371-373.

47 G. Mattioli, S. B. Dkhil, M. I. Saba, G. Malloci, C. Melis, P. Alippi, F. Filippone, P. Giannozzi, A. K. Thakur, M. Gaceur, O. Margeat, A. K. Diallo, C. Videlot-Ackermann, J. Ackermann, A. A. Bonapasta and A. Mattoni, Interfacial Engineering of P3HT/ZnO Hybrid Solar Cells Using Phthalocyanines: A Joint Theoretical and Experimental Investigation, Adv. Energy Mater., 2014, 4, 1301694.

48 F. Bencheikh, D. Duché, C. M. Ruiz, J.-J. Simon and L. Escoubas, Study of Optical Properties and Molecular Aggregation of Conjugated Low Band Gap Copolymers: PTB7 and PTB7-Th, J. Phys. Chem. C, 2015, 119, 24643-24648. 